\title{
A comparison study between GeXP-based multiplex-PCR and serology assay for Mycoplasma pneumoniae detection in children with community acquired pneumonia
}

Le Wang ${ }^{1}$, Zhishan Feng', Mengchuan Zhao', Shuo Yang ${ }^{1}$, Xiaotong Yan', Weiwei Guo', Zhongren Shi* and Guixia Li ${ }^{1}, 2^{*}$

\begin{abstract}
Background: Diagnosis of community-acquired pneumonia (CAP) caused by Mycoplasma pneumoniae (Mp) in children has been hampered by difficulty in obtaining convalescent serum and time constraints. In this study, the two diagnostic assays that targeted respectively on Mp-antibody and Mp-DNA were retrospectively investigated.

Methods: A total of 3146 children were clinically diagnosed to have CAP and were confirmed by chest X-ray during March 2015 to February 2016 in Children's hospital of Hebei Province (China). Both of the sera and sputum samples were collected in $24 \mathrm{~h}$ after their admission. The Mp-antibody was examined by the passive particle agglutination assay and a fourfold or greater increase of antibody titers of paired sera or $\geqq 1: 160$ titer of single serum was set as the serology positive. Mp-DNA in the sputum samples was tested by a multiplex-PCR method named GeXP assay (multiplex PCR combined with automated capillary electrophoresis). In order to eliminate the false positive results caused by the asymptomatic carriage after infected by $M$. pneumoniae, the inconsistent samples were tested by the real-time isothermal transcription-mediated RNA amplification assay (SAT).

Results: The inter-rated agreement test was performed in 3146 CAP patients, with a highest kappa value in the schoolage children as 0.783. There were 6.29\% (198/3146) cases showed inconsistent results determined by GeXP and serology assay. All of the $19 \mathrm{GeXP}(+) /$ Serology (-) samples and a randomly chosen 27 from $179 \mathrm{GeXP(-)/Serology}(+)$ samples were tested by SAT assay, and a $97.8 \%$ diagnosis agreement was observed between SAT and GeXP assay, but not with the serology assay. In addition, patients who were detected only by serology or only by multiplexPCR were significantly younger than those with both methods positive (3.0 and 1.5 years vs. 5.0 years, $p<0$. 01). The Viral-Mp coinfection accounted for $37.0 \%$ (97/262), which was more common in winter and spring $(p<0.05)$ and in the infantile group $(p<0.01)$, compared to the pure Mp positive ones.

Conclusion: In some children CAP cases, the Mp laboratory diagnosis was inconsistent between serology and multiplex-PCR assay. Verified by the SAT assay, the GeXP showed a more sensitive and reliable performance compared with the serology assay. Furthermore, employing the multiplex-PCR could provide more information on the associated pathogens for clinical assessment of CAP.
\end{abstract}

Keywords: Mycoplasma pneumoniae, Community acquired pneumonia, Multiplex-PCR, Serology

\footnotetext{
* Correspondence: lele19870204@163.com; hbetlgx@126.com

'Institute of Pediatric Research, Children's Hospital of Hebei Province, 133

Zhonghua South Street, Shijiazhuang, Hebei Province 050031, China

Full list of author information is available at the end of the article
}

(c) The Author(s). 2017 Open Access This article is distributed under the terms of the Creative Commons Attribution 4.0 International License (http://creativecommons.org/licenses/by/4.0/), which permits unrestricted use, distribution, and reproduction in any medium, provided you give appropriate credit to the original author(s) and the source, provide a link to the Creative Commons license, and indicate if changes were made. The Creative Commons Public Domain Dedication waiver (http://creativecommons.org/publicdomain/zero/1.0/) applies to the data made available in this article, unless otherwise stated. 


\section{Background}

Mycoplasma pneumoniae (Mp) is a leading cause (about $40 \%$ ) of community-acquired pneumonia (CAP) especially in the pediatric populations [1]. The golden diagnostic criteria of $M$. pneumoniae infection has been considered as the seroconversion or rising IgG titers [2], but the antibody results are susceptible to the children's age and immunity status [3, 4], especially facing to the difficulty in obtaining convalescent serum in a pediatric hospital [5].

Due to the advantages of PCR on its sensitivity, specificity and early detection, large body of literature has been published for using PCR to detect Mp-DNA or RNA, including conventional, nested, real-time, multiplex and isothermal amplification PCR [6]. Among these, the multiplex-PCR has been accepted as a more practical diagnosis method in $M$. pneumoniae CAP, because the existence of clinical similarity resulted from $\mathrm{Mp}$ and other agents [7] and the common appearance of the viral co-infections [8]. Thus, in the recent study, the M. pneumoniae was added into our previously used pathogen panel that included 20 types/subtypes of viruses [9]. Meanwhile, several other groups have also designed the multiplex-PCR for the early detection of $M$. pneumoniae infection [10-17], but so far, the direct comparison between multiplex-PCR and serology test in larger pediatric clinical samples has rarely been reported [6]. Besides, the M. pneumoniae RNA detection (real-time isothermal transcription-mediated RNA amplification assay, Mp-SAT) that targeted on the specific 16SrRNA has been invented and investigated $[18,19]$, which could eliminate the false positive cases resulted from the previous infection or the nonpathogenic carrier state [20].

In this study, sputum samples were obtained and analyzed by a commercial multiplex-PCR kit named GeXP multiplex amplification assay for 13 types/subtypes pathogens (including M. pneumoniae) that were commonly detected in patients with CAP. The passive particle agglutination (PA) assay was used to examine the same patients' Mp-antibody in their serum specimens. A comparison between these two assays was conducted, and the Mp-SAT assay was used to test the inconsistent samples. The possible factors that may contribute to the disagreement results were also analyzed.

\section{Methods}

\section{Study population}

The protocols used in this retrospective study was reviewed and approved by the institutional review board of Children's Hospital of Hebei Province. The written informed consent was obtained from each patient's parent prior to enrollment. We selected specimens over a 1year period (2015-2016) to cover all four seasons. Based on CAP Diagnosis and Management Guidelines [21], a total of 3146 otherwise healthy children aged 0.116.0 years (median, 2.0 years) were confirmed by the chest X-ray and finally enrolled. They respectively received the Mp-antibody and Mp-DNA testing within $24 \mathrm{~h}$ of admission. Patients with congenital heart or lung disease, or with immunosuppression, or had received the immunosuppressive therapy, or had been admitted to a hospital longer than 2 days within the last 90 days were excluded.

\section{Detection of $\mathrm{mp}$-antibody by the passive particle agglutination assay}

The paired serum samples were taken at the presentation of pneumonia and at least 7 days after the first collection of serum. The serum was obtained from $2 \mathrm{~mL}$ whole blood by the separation gel tube. And the determination of Mp-specific antibody was performed using a commercially available micro-particle agglutination test Serodia-MycoII kit (Fujirebio, Tokyo, Japan) according to the manufacturer's instructions [22]. Antibody titers were measured at a range of dilutions (from 1:40 to $1: 20,480)$. Criteria for diagnosis were defined as $>$ or $=4$ found rising for paired sera of M. pneumoniae antibody [2] or single serum of titer $>$ or $=1: 160[23,24]$.

\section{Sputum specimen collection}

Patients were asked to cough and the expectorated sputum was collected. If the child is too young to cough, a sterile negative pressure suction catheter is applied to obtain the oropharyngeal suction (OPS) into transport tube containing $1 \mathrm{ml}$ DMEM medium with $2 \%$ heatinactivated fetal calf serum, $50 \mathrm{IU} / \mathrm{ml}$ of penicillin and $100 \mu \mathrm{g} / \mathrm{ml}$ of streptomycin (Gibco, Beijing, China). The sample was stored at $4{ }^{\circ} \mathrm{C}$ for the same day pathogen nucleic acid extraction. Total nucleic acid (both DNA and RNA) was extracted from $200 \mu \mathrm{L}$ sputum sample and eluted into $30 \mu \mathrm{L}$ nuclease-free water by the EasyPure Viral DNA/RNA Kit (QSJBio, Beijing, China) in accordance with the manufacturer's instructions. Afterwards, $3 \mu \mathrm{L}$ of extracted nucleic acid was analyzed with the GeXP-based assay. The remaining sputum samples were added into equal volume of preservative solution and stored at a $-80{ }^{\circ} \mathrm{C}$ freezer.

\section{Detection of mp-DNA by the automated GenomeLab GeXP genetic analysis system}

The GeXP assay (GenomeLab GeXP Genetic Analysis System) was performed on all specimens for the following 13 different respiratory pathogens,: Influenza A (Flu A), Influenza B (Flu B), Influenza A H1N1 pdm09 (09H1), influenza H3N2 (H3), human parainfluenza virus (HPIV), respiratory syncytial virus (RSV), rhinovirus (HRV), adenovirus (ADV), human metapneumovirus (HMPV), human bocavirus ( $\mathrm{HBoV})$, 
human coronavirus (HCoV), Chlamydia (Ch) and Mycoplasma pneumoniae ( $\mathrm{Mp}$ ), using the 13 Respiratory Pathogens Multiplex Kit (PCR-Capillary Electrophoresis Fragment Analysis) (Health Gene Tech., Ningbo, China). The reverse transcription (RT) and PCR were performed as previously described in Wang, et al. [9]. The analysis was then performed in an automated manner following the established protocol and the data were compiled by the GeXP system software provided by Beckman Coulter.

\section{Detection of mp-rRNA by SAT}

The frozen sputum specimens were thawed on the day the assays were performed. RNA extraction was performed on the MagX automated platform (Rendu Biotech., Shanghai, China), in which the targeted 16SrRNA could be enriched and purified by the magnetic particles. The final RNA was eluted into $30 \mu \mathrm{L}$ nuclease-free water. The negative and positive controls were also introduced into the next Mp-SAT procedure. The reaction was performed as follows: incubation at $60{ }^{\circ} \mathrm{C}$ for $10 \mathrm{~min}$ and $42{ }^{\circ} \mathrm{C}$ for $5 \mathrm{~min}, 10 \mu \mathrm{L}$ of SAT enzyme was added into the reaction. The Mp-SAT was completed on a real-time thermocycler (Veriti Thermal Cycler, Applied Biosystems China) in following steps: step1, $42{ }^{\circ} \mathrm{C}$ for $1 \mathrm{~min}$; step 2 was repeated for 40 cycles. The fluorescent light channel was set as FAM (sample channel) and HEX (internal control channel). The amplified products were then assessed using the SAT analysis system (Rendu Biotech), and a real-time PCR Ct value $\leqq 30$ is defined as positive.

\section{Statistical analysis}

The Pearson and Linear-by-linear association chisquared test was used to compare sex, admission season and age subgroups. The Kruskal-Wallis test was used to compare mean age at onset of illness. SPSS 13.0.1 statistics package (SPSS Inc., Chicago, USA) software was used for all statistical analysis. $p<0.05$ was considered statistically significant.

\section{Results}

\section{M. pneumoniae detection by serology versus multiplex-} PCR testing

Sputum and serum specimens collected from 3146 hospitalized children were tested by GeXP assay and PA assay, respectively. A total of 243 samples $(7.72 \%, 243 /$ 3146) were both positive and 2705 samples $(85.98 \%$, 2705/3146) were both negative based on these two methods. The inconsistent samples accounted for $6.29 \%$ $(198 / 3146)$. The Kappa value was ordinary $(\kappa=0.677$, $p<0.01)$, and the highest kappa value $(\mathrm{\kappa}=0.783)$ was observed in the school-age children group (Table 1).
Table 1 The consistency of test results for M. Pneumoniae between serology and multiplex-PCR testing

\begin{tabular}{lllllll}
\hline & MX- & \multicolumn{2}{l}{ Serology } & & \multirow{2}{l}{$\begin{array}{l}\text { Kappa } \\
\text { Value }\end{array}$} & $P$ \\
\cline { 3 - 4 } & PRC & + & - & & 0.486 & $<0.01$ \\
\hline $0-3 \mathrm{yr}$ & + & 52 & 14 & & \\
& - & 78 & 855 & & $<0.01$ \\
$3-6 \mathrm{yr}$ & + & 81 & 3 & 0.723 & \\
& - & 51 & 910 & & $<0.01$ \\
$>6 \mathrm{yr}$ & + & 110 & 2 & 0.783 & \\
& - & 50 & 942 & & \\
Total & + & 243 & 19 & 0.677 & $<0.01$ \\
& - & 179 & 2705 & & \\
\hline
\end{tabular}

To better understand the discordant samples, the terms of 'false positive' and 'false negative' rates of serology were introduced. The premise to use them is to assume the results of multiplex-PCR as gold standard. If the sample is tested to be Serology $(+) /$ Multiplex-PCR $(-)$, it is presented as 'false positive'; to be Serology $(-)$ /Multiplex-PCR (+), it is presented as 'false negative'. We found that both of the 'false positive' and 'false negative' rates of serology were significantly $(p<0.001)$ associated with age (Table 2). The 'false positive' samples took a proportion of $60 \%(78 / 130)$ in ages $0-3,39 \%$ (51/ $132)$ in $3-6$ years, and $31 \%(50 / 160)$ in ages $>6$ years. Similarly, 'false negative' samples accounted for $21 \%(14 /$ $66), 4 \%(3 / 84)$ and $2 \%(2 / 112)$ in ages $0-3,3-6$ and $>6$ years old, respectively.

Of the total 422 patients with positive serology results, paired sera were collected from 26 patients $(6.2 \%)$. Interestingly, the 26 paired sera samples were in good agreement with multiplex-PCR results: 92\% (24/26) cases with four fold increase titer which were corresponded to the multiplex-PCR positive.

In addition, children in whom M. pneumoniae was detected by serological or by multiplex-PCR alone were significantly younger than those who were detected by both methods $(Z=-4.20, p<0.01)$. But no significant differences were observed for their admission season $(p=0.165)$ or sex $(p=0.338)$ (Table 3$)$.

\section{Testing of specimens with mp-SAT assay}

A total of 46 cases with inconsistent results were reanalyzed by the Mp-SAT assay. We randomly chose 27 samples from 179 cases that had been determined to be Serology(+)/MX-PCR (-), together with the whole 19 Serology (-)/MX-PCR(+) cases. Among the 46 sputum samples redo the Mp-SAT assay, we found $97.8 \%$ diagnosis agreement between SAT and GeXP assay. A total of 18 Serology (-)/MX-PCR (+) cases were determined to be SAT positive, and the whole 27 Serology $(+) / M X-P C R$ 
Table 2 The age-dependent false positive and false negative rates of serology assay

\begin{tabular}{|c|c|c|c|c|c|c|}
\hline Age & $\begin{array}{l}\text { False } \\
\text { positive rate }\end{array}$ & $\begin{array}{l}\text { Statistic } \\
\text { value }\end{array}$ & $P$ & $\begin{array}{l}\text { False } \\
\text { negative } \\
\text { rate }\end{array}$ & $\begin{array}{l}\text { Statistic } \\
\text { value }\end{array}$ & $P$ \\
\hline $0-3$ year & $60 \%(78 / 130)$ & & & $21 \%(14 / 66)$ & & \\
\hline $3-6$ year & $39 \%(31 / 132)$ & $23.532^{\mathrm{a}}$ & $<0.001$ & $4 \%(3 / 84)$ & $20.500^{\mathrm{a}}$ & $<0.001$ \\
\hline$>6$ year & $31 \%(50 / 160)$ & & & $2 \%(2 / 112)$ & & \\
\hline
\end{tabular}

${ }^{a}$ Linear-by-Linear Association

(-) cases were all tested to be SAT negative (Additional file 1 Table S1).

\section{Mp coinfection with other pathogens}

Ninety-seven patients $(37.0 \%, 97 / 262)$ had other causative pathogens besides $M$. pneumoniae. Among these patients, HRV was the most detected (20.2\%, 53/262), followed with HPIV, FluB, ADV, RSV, 09H1, H3, HCoV, HBoV and HMPV (Table 4).

In the comparison of two patients groups that infected only with $M$. pneumoniae and mixed infected with other viruses, the significant discrepancies existed in different season and age subgroups, but not in the sex groups (Table 5).

The seasonal distribution analysis revealed that, patients infected only with $M$. pneumoniae were more than the mixed infection patients during summer and autumn. But in spring and winter, the mixed infection patients showed to be predominate $\left(\mathrm{X}^{2}=5.12, p=0.023\right)$. Interestingly, the positive detection rate of school-age children was highest in the $M$. pneumoniae only group, but the lowest in the mixed infection group $\left(x^{2}=18.96, p<0.01\right)$.

\section{Discussion}

The nucleic acid amplification techniques (NAATs) targeted towards DNA or RNA have increasingly been explored for identification of pathogens including $M$. pneumoniae in infectious respiratory diseases [10-17]. So far, only a few studies have described the application of NAATs for pathogen detection in children with CAP [25-27]. Determination as well as comparison between laboratory diagnosis methods of $M$. pneumoniae infection for childhood CAP in larger clinical database has not been reported. In the present study, we applied a multiplex-PCR, named GeXP assay, to detected 13 types of pathogens including M. pneumoniae in 3146 sputum samples from hospitalized CAP children. Meanwhile, their serum specimens were also collected to be tested the antibody against $M$. pneumoniae. After the comparison between serology and GeXP assays on the same patient, about $93.7 \%$ of cases were diagnosed to be either positive or negative based on these 2 methods. We randomly chose 46 samples from 198 samples that had been tested to be inconsistent by serology and GeXP assays, redo the Mp-SAT and found $97.8 \%$ diagnosis agreement between SAT and GeXP assays, but not with the serology testing. Further analysis revealed that children in whom $M$. pneumoniae was only examined to be positive by GeXP or serology were significantly younger than those of both methods positive. About 37\% of patients have virus-Mp coinfection, which were most observed in infantile patients. Seasonal distribution analysis revealed that the virus-Mp coinfection were predominant in spring and winter, while Mp-only infection was more frequently identified in summer and autumn.

Only a few reports have thus far described the comparison between serology and mono-PCR assays for $M$. pneumoniae detection in pediatric CAP patients [28-31]. Using the paired sera samples, three independent research groups all observed excellent diagnosis agreement between these 2 methods [28-30], in

Table 3 Characteristics of $M$. Pneumoniae detection by serology and multiplex-PCR testing

\begin{tabular}{|c|c|c|c|c|c|c|}
\hline \multirow{2}{*}{\multicolumn{2}{|c|}{ Characteristics }} & \multicolumn{3}{|l|}{ Values of the Cases Tested } & \multirow[b]{2}{*}{$\begin{array}{l}\text { Statistic } \\
\text { value }\end{array}$} & \multirow[b]{2}{*}{$P$} \\
\hline & & $\begin{array}{l}\text { Serology }(+) / M X-P C R(+) \\
(n=243)\end{array}$ & $\begin{array}{l}\text { Serology }(-) / M X-P C R(+) \\
(n=19)\end{array}$ & $\begin{array}{l}\text { Serology }(+) / M X-P C R(-) \\
(n=179)\end{array}$ & & \\
\hline \multicolumn{2}{|c|}{ Age (Median) } & 5.0 & 1.5 & 3.0 & $35.423^{\mathrm{a}}$ & $<0.01$ \\
\hline \multirow[t]{4}{*}{ Season (n) } & Spring & 27 & 2 & 35 & $9.150^{b}$ & 0.165 \\
\hline & Summer & 42 & 2 & 28 & & \\
\hline & Autumn & 53 & 7 & 33 & & \\
\hline & Winter & 121 & 8 & 83 & & \\
\hline \multirow[t]{2}{*}{$\operatorname{Sex}(n)$} & Male & 142 & 12 & 93 & $2.169^{\mathrm{b}}$ & 0.338 \\
\hline & Female & 101 & 7 & 86 & & \\
\hline
\end{tabular}

${ }^{a}$ Kruskal-Wallis test

b Pearson Chi-Square 
Table 4 The rates of co-infection of $M$. pneumoniae CAP patients by other respiratory pathogens

\begin{tabular}{lll}
\hline & Pathogens & Positive Num. \\
\hline 1 & No other pathogens & $165(63.0 \%)$ \\
2 & HRV & $53(20.2 \%)$ \\
3 & HPIV & $15(5.7 \%)$ \\
4 & FluB & $12(4.6 \%)$ \\
5 & ADV & $9(3.4 \%)$ \\
6 & RSV & $9(3.4 \%)$ \\
7 & O9H1 & $8(3.1 \%)$ \\
8 & H3 & $5(1.9 \%)$ \\
9 & HCoV & $4(1.5 \%)$ \\
10 & HBoV & $4(1.5 \%)$ \\
11 & HMPV & $2(0.8 \%)$ \\
\hline
\end{tabular}

contrast to our findings and Kim's [31]. This discrepancy is mainly attributed to the proportion of paired sera. Because in our results, only $13 \%$ patients provided their second sera specimen, the good concordance could be observed between these paired sera with multiplex-PCR, On the other hand, after comparing the mono-PCR and serology assay, Kim proposed that a single titer $\geqq 1: 640$ were considered to indicate the acute $M$. pneumoniae infection [31]. But in clinical, a presumptive diagnosis could be made from a single acute-phase serum titer $\geqq 1: 160$ [24]. Therefore, if we interpret the Multiplex-PCR positive samples as truly indicating $\mathrm{Mp}$ infection, the high 'false positive rate' of serology testing $(42 \%, 179 / 422)$ may caused by the proportion of paired sera and the criteria of diagnosis. Besides that, the serology 'false positive rate' was probably due to the other two aspects: Firstly, the serology

Table 5 Comparison of age, season and sex characteristics between children with only M. pneumoniae and those with mixed infection by at least one respiratory virus

\begin{tabular}{|c|c|c|c|c|c|c|}
\hline & & \multirow[b]{2}{*}{$\mathrm{N}$} & \multicolumn{2}{|c|}{ Positive rate $(n)$} & \multirow{2}{*}{$\begin{array}{l}\text { Statistic } \\
\text { value }\end{array}$} & \multirow[t]{2}{*}{$P$} \\
\hline & & & Mp only & $\mathrm{Mp} w / \mathrm{t}$ virus & & \\
\hline \multirow[t]{2}{*}{ Sex } & Male & 154 & $61.7 \%(95)$ & $38.3 \%(59)$ & $0.27^{\mathrm{a}}$ & 0.606 \\
\hline & Female & 108 & $64.8 \%(70)$ & $35.2 \%(38)$ & & \\
\hline \multirow[t]{4}{*}{ Season } & Spring & 32 & $68.8 \%(22)$ & $31.2 \%(10)$ & $5.12^{\mathrm{b}}$ & 0.023 \\
\hline & Summer & 43 & $72.1 \%(31)$ & $27.9 \%(12)$ & & \\
\hline & Autumn & 61 & $72.1 \%(44)$ & $27.9 \%(17)$ & & \\
\hline & Winter & 126 & $54.0 \%(68)$ & $46.0 \%(58)$ & & \\
\hline \multirow[t]{4}{*}{ Age } & $0-1 \mathrm{yr}$ & 16 & $25.0 \%(4)$ & $75.0 \%(12)$ & $18.96^{\mathrm{b}}$ & $<0.01$ \\
\hline & $1-3 y r$ & 50 & $46.0 \%(23)$ & $54.0 \%(27)$ & & \\
\hline & $3-6 y r$ & 83 & $67.5 \%(56)$ & $32.5 \%(27)$ & & \\
\hline & $>6 \mathrm{yr}$ & 113 & $72.6 \%(82)$ & $27.4 \%(31)$ & & \\
\hline
\end{tabular}

a Pearson Chi-Square

${ }^{\mathrm{b}}$ Linear-by-Linear Association assay is claimed to detect both of $\mathrm{Mp}-\operatorname{IgM}$ and $\operatorname{IgG}$ [22], the positive serology results may be caused by an earlier (not current) Mp infection, which is still detectable in the blood. Alternatively, the current infection truly exists, but the amount of organism was below the detection limit of multiplex-PCR. It has been reported that the diagnostic accuracy of PCR may decrease at $\geq 7$ days after onset of disease in contrast to serology [32], especially patients who receive week duration of the antibiotic treatment [31].

Besides these mono-PCR studies, as reviewed by Loens et al. [6], several groups have applied the multiplex-PCR in the detection of $M$. pneumoniae infection, but the comparison assays were set as culture and/or monoPCR, which are more suitable for accuracy validation during the methodology establishment process rather than obtaining the clinical diagnostic significance. In addition, Due to the high viral coinfection prevalence reported by Chen (25.9\% [33]) and ours (37.0\%), it is essential to recommend the use of multiplex-PCR assay to provide more pathogen information. More importantly, in Mp IgM-positive children, a negative PCR result was reported to be associated with coinfection by other pathogens [32]. Our results also demonstrated that the youngest children group exhibited highest Serology $(+) /$ Multiplex-PCR (-) rate and highest coinfection rate. In young children, since the serology positive cases may be result from other pathogen infection, the multiplex-PCR should be used to rectify these sorts of false positive cases determined by serology. Furthermore, a number of studies have demonstrated a weak or deferred antibody response to M. pneumoniae in young children [31-36], suggesting a possible reason leading to the highest Serology (-)/Multiplex-PCR (+) rate observed in the youngest patients group in our study. In conclusion, owing to the high coinfection rate and weak antibody response in young children, the Mp infection is needed to be monitored not only by the serology assay. A combination of serology and multiplex-PCR allows for both decreased 'false positive' and 'false negative' rates of serology assay.

In the present study, the inconsistent results were observed and took a $6.29 \%$ proportion, beside of $90 \%$ Multiplex-PCR (-)/Serology (+) samples mentioned above, the remaining $10 \%$ discordant samples were Multiplex-PCR (+)/Serology (-). Previous work has shown that the colonization of $M$. pneumoniae may cause the false positive results [37-39]. To rule out the possible false positive results of multiplex-PCR (targeting Mp-DNA) caused by colonization, the SAT assay (targeting Mp-RNA) were applied and we found that a overwhelming majority $(94.7 \%, 18 / 19)$ of Multiplex-PCR $(+) /$ Serology $(-)$ sputum specimens were proved to be SAT positive. On the contrast, the randomly selected Multiplex-PCR (-)/Serology (+) sputum specimens were 
all observed to be SAT negative. These data suggest that the multiplex-PCR assay would be more reliable when the serology assay exhibits the opposite results. However, we felt a verification experiment with larger sample size should be used in future work. Another limitation of this work is that the highly specialized equipment is needed, namely an automated nucleic acid extraction system, which could carried out 48 samples at one time in about $1 \mathrm{~h}$. Many primary hospitals or clinical laboratories do not have this equipment, and the manual work would greatly increase the turnaround time.

\section{Additional file}

Additional file 1: Table S1. The Ct value of 18 Serology (-)/MX-PCR (+) cases. (DOC $35 \mathrm{~kb}$ )

\section{Abbreviations}

09H1: Influenza A H1N1 pdm09; ADV: Adenovirus; CAP: Community acquired pneumonia; Ch: Chlamydia; FluA: Influenza virus A; FluB: Influenza virus B; GeXP assay: GenomeLab Genetic Analysis System; H3: Influenza H3N2; HBoV: Human bocavirus; HCoV: Human coronavirus; hMPV: Human metapneumovirus; HRV: Human rhinovirus; Mp or M: Pneumoniae, Mycoplasma pneumoniae; MX-PCR: Multiplex-PCR; NAATs: Nucleic acid amplification techniques; PA assay: Particle agglutination assay; PIV: Parainfluenza virus; RSV: Respiratory syncytial virus; RT-PCR: Reverse transcription polymerase chain reaction; SAT: Real-time isothermal transcription-mediated RNA amplification assay

\section{Acknowledgements}

We sincerely thank all the participants for their support. We also thank Dr. Hong Yan and Wenchao Zhang from the Department of Laboratory Medicine, Children's Hospital of Hebei Province, Shijiazhuang, China, for their help with recruitments of subjects.

\section{Funding}

None.

\section{Availability of data and materials}

The datasets generated and/or analysed during the current study are available in the [Figshare] repository, [https://figshare.com/articles/ MPAccessibleData_GeXPPos_xIs/5193577]. The data showed the positive sputum and serum specimens collected from 3146 hospitalized children which were tested by GeXP assay and PA assay, respectively.

\section{Authors' contributions}

LW carried out the Ge-XP and PA assay, performed the statistical analysis and drafted the manuscript. WG participated in the validation. $X Y$ and $M Z$ carried out the SAT assay. GL and ZS participated in the design of the study. GL conceived of the study, and participated in its design and coordination and helped to draft the manuscript. All authors read and approved the final manuscript.

\section{Ethics approval and consent to participate}

The protocols used in this retrospective study was reviewed and approved by the institutional review board of Children's Hospital of Hebei Province. The written informed consent was obtained from each patient's parent prior to enrollment.

\section{Consent for publication}

Not applicable.

\section{Publisher's Note}

Springer Nature remains neutral with regard to jurisdictional claims in published maps and institutional affiliations.

\section{Author details}

${ }^{1}$ Institute of Pediatric Research, Children's Hospital of Hebei Province, 133

Zhonghua South Street, Shijiazhuang, Hebei Province 050031, China.

Department of Laboratory Medicine, Children's Hospital of Hebei Province,

Shijiazhuang 050031, China.

Received: 3 November 2016 Accepted: 18 July 2017

Published online: 25 July 2017

Reference

1. Lee KY. Pediatric respiratory infections by Mycoplasma pneumoniae. Expert Rev Anti-Infect Ther. 2008;6(4):509-21.

2. She RC, Thurber A, Hymas WC, Stevenson J, Langer J, Litwin CM, Petti CA. Limited utility of culture for Mycoplasma pneumoniae and Chlamydophila pneumoniae for diagnosis of respiratory tract infections. Eur J Clin Microbiol. 2010:48(9):3380-2.

3. Han X, Li S, Lu S, Liu L, Li S, Zhang J. Amplification of $16 \mathrm{~S}$ rDNA by nested PCR for measurement of Mycoplasma pneumoniae DNA over time: clinical application. J Med Microbiol. 2012;61(Pt 3):426-30.

4. Principi N, Esposito S. Emerging role of Mycoplasma pneumoniae and Chlamydia pneumoniae in paediatric respiratory-tract infections. Lancet Infect Dis. 2001;1(5):334-44.

5. Youn YS, Lee KY, Hwang JY, Rhim JW, Kang JH, Lee JS, Kim JC. Difference of clinical features in childhood Mycoplasma pneumoniae pneumonia. BMC Pediatr. 2010;10:48

6. Loens K, leven M. Mycoplasma pneumoniae: current knowledge on nucleic acid amplification techniques and serological diagnostics. Front Microbiol. 2016;7:448.

7. Thompson KS, Yonke ML, Rapley JW, Cobb CM, Johnson V. Relationship between a self-reported health questionnaire and laboratory tests at initial office visits. J Periodontol. 1999:70(10):1153-7.

8. Bezerra PG, Britto MC, Correia JB, Duarte Mdo C, Fonceca AM, Rose K, Hopkins MJ, Cuevas LE, McNamara PS. Viral and atypical bacterial detection in acute respiratory infection in children under five years. PLoS One. 2011; 6(4):e18928.

9. Wang L, Zhao M, Shi Z, Feng Z, Guo W, Yang S, Liu L, Li G. A GeXP-based assay for simultaneous detection of multiple viruses in hospitalized children with community acquired pneumonia. PLoS One. 2016;11(9):e0162411.

10. Puppe W, Weigl J, Grondahl B, Knuf M, Rockahr S, von Bismarck P, Aron G, Niesters $H G$, Osterhaus AD, Schmitt HJ. Validation of a multiplex reverse transcriptase PCR ELISA for the detection of 19 respiratory tract pathogens. Infection. 2013:41(1):77-91.

11. Simoes EA, Patel C, Sung WK, Lee CW, Loh KH, Lucero M, Nohynek H, Nai G, Thien PL, Koh CW, et al. Pathogen chip for respiratory tract infections. J Clin Microbiol. 2013;51(3):945-53.

12. Hirama T, Minezaki S, Yamaguchi T, Kishi E, Kodama K, Egashira H, Kobayashi K, Nagata M, Ishii T, Nemoto M, et al. HIRA-TAN: a real-time PCR-based system for the rapid identification of causative agents in pneumonia. Respir Med. 2014;108(2):395-404

13. Weinberg GA, Schnabel KC, Erdman DD, Prill MM, Iwane MK, Shelley LM, Whitaker BL, Szilagyi PG, Hall CB. Field evaluation of TaqMan Array card (TAC) for the simultaneous detection of multiple respiratory viruses in children with acute respiratory infection. J Clin Virol. 2013;57(3):254-60.

14. Ji M, Lee NS, Oh JM, Jo JY, Choi EH, Yoo SJ, Kim HB, Hwang SH, Choi SH, Lee SO, et al. Single-nucleotide polymorphism PCR for the detection of Mycoplasma pneumoniae and determination of macrolide resistance in respiratory samples. J Microbiol Methods. 2014;102:32-6.

15. Zhao F, Liu L, Tao X, He L, Meng F, Zhang J. Culture-independent detection and genotyping of Mycoplasma pneumoniae in clinical specimens from Beijing. China PloS One. 2015;10(10):e0141702

16. Shen H, Zhu B, Wang S, Mo H, Wang J, Li J, Zhang C, Zeng H, Guan L, Shi $W$, et al. Association of targeted multiplex PCR with resequencing microarray for the detection of multiple respiratory pathogens. Front Microbiol. 2015;6:532.

17. Nummi M, Mannonen L, Puolakkainen M. Development of a multiplex real-time PCR assay for detection of Mycoplasma pneumoniae, Chlamydia pneumoniae 
and mutations associated with macrolide resistance in Mycoplasma pneumoniae from respiratory clinical specimens. SpringerPlus. 2015;4:684.

18. Feng Xueli LQ, Xu B, Lin S, Weiwei J, Shen C, Adong S. Evaluation of RNA simultaneous amplification and testing for detection of Mycoplasma pneumoulae pneumonia in children. Chin J Appl Clin Pediatr. 2016:16(31).

19. Guo Li SL, Guo Y, Adong S. Clinical value of Mycoplasma pneumoniae RNA detection in the monitoring of Mycolasma pneumoniae pneumonia treatment in children. Chin J Evid Based Pediatr. 2016;02(11)

20. Foy HM. Infections caused by Mycoplasma pneumoniae and possible carrier state in different populations of patients. Clin Infect Dis. 1993;17(Suppl 1): S37-46.

21. He LX. Guidelines for the diagnosis and treatment of community-acquired pneumonia: learning and practicing. Zhonghua Jie He He Hu Xi Za Zhi. 2006;29(10):649-50.

22. Barker CE, Sillis M, Wreghitt TG. Evaluation of Serodia Myco II particle agglutination test for detecting Mycoplasma pneumoniae antibody: comparison with mu-capture ELISA and indirect immunofluorescence. J Clin Pathol. 1990;43(2):163-5.

23. Templeton KE, Scheltinga SA, Graffelman AW, Van Schie JM, Crielaard JW, Sillekens P, Van Den Broek PJ, Goossens H, Beersma MF, Claas EC. Comparison and evaluation of real-time $P C R$, real-time nucleic acid sequence-based amplification, conventional PCR, and serology for diagnosis of Mycoplasma pneumoniae. J Clin Microbiol. 2003;41(9):4366-71.

24. Matas L, Dominguez J, De Ory F, Garcia N, Gali N, Cardona PJ, Hernandez A, Rodrigo C, Ausina V. Evaluation of meridian ImmunoCard Mycoplasma test for the detection of Mycoplasma pneumoniae-specific lgM in paediatric patients. Scand J Infect Dis. 1998;30(3):289-93.

25. Juven T, Mertsola J, Waris M, Leinonen M, Meurman O, Roivainen M, Eskola J, Saikku P, Ruuskanen O. Etiology of community-acquired pneumonia in 254 hospitalized children. Pediatr Infect Dis J. 2000;19(4):293-8.

26. Cantais A, Mory O, Pillet S, Verhoeven PO, Bonneau J, Patural H, Pozzetto B. Epidemiology and microbiological investigations of community-acquired pneumonia in children admitted at the emergency department of a university hospital. J Clin Virol. 2014;60(4):402-7.

27. Rhedin S, Lindstrand A, Hjelmgren A, Ryd-Rinder M, Ohrmalm L, Tolfvenstam T, Ortqvist A, Rotzen-Ostlund M, Zweygberg-Wirgart B, Henriques-Normark B, et al. Respiratory viruses associated with communityacquired pneumonia in children: matched case-control study. Thorax. 2015; 70(9):847-53.

28. Gotoh K, Nishimura N, Ohshima Y, Arakawa Y, Hosono H, Yamamoto Y, Iwata Y, Nakane K, Funahashi K, Ozaki T. Detection of Mycoplasma pneumoniae by loop-mediated isothermal amplification (LAMP) assay and serology in pediatric community-acquired pneumonia. J Infect Chemother. 2012;18(5):662-7.

29. Chaudhry R, Sharma S, Javed S, Passi K, Dey AB, Malhotra P. Molecular detection of Mycoplasma pneumoniae by quantitative real-time PCR in patients with community acquired pneumonia. Indian J Med Res. 2013; 138:244-51

30. Medjo B, Atanaskovic-Markovic M, Radic S, Nikolic D, Lukac M, Djukic S. Mycoplasma pneumoniae as a causative agent of community-acquired pneumonia in children: clinical features and laboratory diagnosis. Ital J Pediatr. 2014;40:104.

31. Kim NH, Lee JA, Eun BW, Shin SH, Chung EH, Park KW, Choi EH, Lee HJ. Comparison of polymerase chain reaction and the indirect particle agglutination antibody test for the diagnosis of Mycoplasma pneumoniae pneumonia in children during two outbreaks. Pediatr Infect Dis J. 2007; 26(10):897-903.

32. Chang HY, Chang LY, Shao PL, Lee PI, Chen JM, Lee CY, Lu CY, Huang LM. Comparison of real-time polymerase chain reaction and serological tests for the confirmation of Mycoplasma pneumoniae infection in children with clinical diagnosis of atypical pneumonia. Journal of microbiology, immunology, and infection =. Wei mian yu gan ran za zhi. 2014;47(2):137-44.

33. Chen LL, Cheng YG, Chen ZM, Li SX, Li XJ, Wang YS. Mixed infections in children with Mycoplasma pneumoniae pneumonia. Zhonghua Er Ke Za Zhi. 2012;50(3):211-5.

34. Ozaki T, Nishimura N, Ahn J, Watanabe N, Muto T, Saito A, Koyama N, Nakane K, Funahashi K. Utility of a rapid diagnosis kit for Mycoplasma pneumoniae pneumonia in children, and the antimicrobial susceptibility of the isolates. J Infect Chemother. 2007;13(4):204-7.

35. Lind K, Bentzon MW. Ten and a half years seroepidemiology of Mycoplasma pneumoniae infection in Denmark. Epidemiol Infect. 1991;107(1):189-99.
36. Bogaert D, van Belkum A, Sluijter M, Luijendijk A, de Groot R, Rumke HC, Verbrugh HA, Hermans PW. Colonisation by Streptococcus Pneumoniae and Staphylococcus Aureus in healthy children. Lancet. 2004;363(9424):1871-2.

37. Spuesens EB, Fraaij PL, Visser EG, Hoogenboezem T, Hop WC, van Adrichem LN, Weber F, Moll HA, Broekman B, Berger MY, et al. Carriage of Mycoplasma pneumoniae in the upper respiratory tract of symptomatic and asymptomatic children: an observational study. PLoS Med. 2013;10(5): e1001444.

38. Meyer Sauteur PM, van Rossum AM, Vink C. Mycoplasma pneumoniae in children: carriage, pathogenesis, and antibiotic resistance. Curr Opin Infect Dis. 2014;27(3):220-7.

39. Spuesens EB, Meyer Sauteur PM, Vink C, van Rossum AM. Mycoplasma pneumoniae infections-does treatment help? J Inf Secur. 2014;69(Suppl 1):S42-6.

\section{Submit your next manuscript to BioMed Central and we will help you at every step:}

- We accept pre-submission inquiries

- Our selector tool helps you to find the most relevant journal

- We provide round the clock customer support

- Convenient online submission

- Thorough peer review

- Inclusion in PubMed and all major indexing services

- Maximum visibility for your research

Submit your manuscript at www.biomedcentral.com/submit
) Biomed Central 